\title{
De Novo Synthesis of Brush Border Membrane Enzymes During Intestinal Perfusion with Bile Salt in the Rat
}

\author{
By Bärbel Bossmann and R. J. Haschen \\ Institute of Clinical Biochemistry, Martin Luther University Halle-Wittenberg, Halle, GDR
}

(Received October 31, 1983/March 8, 1984)

\begin{abstract}
Summary: Jejunal perfusion in the rat with Ringer solution containing $10 \mathrm{mmol} / \mathrm{l}$ taurocholate removes considerable quantities of protein and brush border membrane enzymes from the intestinal epithelium. The duration of the experiments was $7.5 \mathrm{~h}$. One group of animals was given $200 \mu \mathrm{g}$ cycloheximide per $100 \mathrm{~g}$ body weight intramuscularly $1 \mathrm{~h}$ before start of the perfusion. Serial estimations of protein and of four brush border membrane enzymes (alanine aminopeptidase, alkaline phosphatase, $\gamma$-glutamyl transferase, and enteropeptidase) were done in the perfusate. The results provide evidence that during the experiments an increasing proportion of the enzymes stems from de novo synthesis. This is consistent with the concept that after loss of 10-30 per cent of enzyme the molecules are replaced by newly synthesized material, provided that the energy metabolism of the mucosa cells remains intact.
\end{abstract}

De novo-Synthese von Enzymen der Bürstensaummembran der Ratte während Perfusion des Darms mit Gallensalz

Zusammenfassung: Bei der Ratte werden durch jejunale Perfusion mit Ringer-Lösung, die $10 \mathrm{mmol} / \mathrm{l}$ Taurocholat enthält, beträchtliche Mengen von Eiweiß und Bürstensaumenzymen aus dem Dünndarmepithel entfernt. Die Perfusionsdauer betrug 7,5 h. Eine Gruppe der Tiere erhielt $1 \mathrm{~h}$ vor Beginn der Perfusion $200 \mu \mathrm{g}$ Cycloheximid je $100 \mathrm{~g}$ Körpergewicht i.m. Im Perfusat wurden Eiweiß und vier Bürstensaumenzyme in Abständen bestimmt. Die Ergebnisse beweisen, dạ während der Versuche ein zunehmender Anteil der Enzyme aus der Neusynthese stammt. Dies ist mit der Vorstellung vereinbar, daß die Enzymmoleküle nach dem Verlust von 10-30\% durch neusynthetisiertes Material ersetzt werden, vorausgesetzt, da $\beta$ die Energiesituation in den Mucosazellen intakt bleibt.

\section{Introduction}

As demonstrated in a previous paper (1) bile salts are capable of removing considerable quantities of enzymes from the brush border of the intestinal mucosa of the rat. During a $2.5 \mathrm{~h}$ perfusion with Ringer solution containing $10 \mathrm{mmol} / \mathrm{l}$ taurocholate at least 10 per cent of the original quantity are released from the plasma membrane. At the same time, the mucosa epithelium remains intact with respect to both morphology and function. The essential electronmicroscopic observation is a rarefication of the apical glycocalyx. Practically no lysosomal or mitochondrial enzymes are released into the perfusion medium.
The question arises whether the brush border enzyme molecules that appear in the medium are preformed or originate from de novo synthesis. To answer this question experiments with cycloheximide, a well-known inhibitor of protein biosynthesis, were done.

\section{Material and Methods}

Female white Wistar rats of about $200 \mathrm{~g}$ body weight were used. After narcosis with Brevinarcon (ethylbutyl thiobarbital-sodium) $20 \mathrm{~cm}$ of the proximal jejunum were cannulated from both ends and perfused in a closed system as described previously (1). 
The animals were divided into three groups.

(I) perfusion with Ringer solution $(9.5 \mathrm{~g} \mathrm{NaCl}, 0.5 \mathrm{~g} \mathrm{KCl}, 0.2 \mathrm{~g}$ $\mathrm{CaCl}_{2}, 0.15 \mathrm{~g} \mathrm{NaHCO}, 1.0 \mathrm{~g}$ glucose per liter) $(n=5)$.

(II) perfusion with Ringer solution containing $10 \mathrm{mmol} / \mathrm{l}$ sodium taurocholate $(n=5)$, and

(III) the samc as (II) after the animals had received $200 \mu \mathrm{g}$ cycloheximide $/ 100 \mathrm{~g}$ body weight intramuscularly $1 \mathrm{~h}$ before the start of the experiment $(n=6)$.

The duration of the perfusion was prolonged to $7.5 \mathrm{~h}$. Samples were taken after $0.25,1,1.5,2,2.5,3.5,4.5,6$ and $7.5 \mathrm{~h}$. Protein and 4 plasma membrane enzymes, viz. alanine aminopeptidase (EC 3.4.11.2), alkaline phosphatase (EC 3.1.3.1), $\gamma$-glutamyl transferase (EC 2.3.2.2) and enteropeptidase (EC 3.4.21.9) were estimated according to methods used in our previous work. With the exception of enteropeptidase the measured enzyme activities were corrected for the direct influence of bile salt (1).

\section{Results}

As can be seen from figures 1 and 2 the release by taurocholate of enzymes and protein is clearly inhibited by cycloheximide. In all cases significant differences (between $p<0.05$ and $p<0.001$ ) are obtained. The moment at which the curves begin to diverge seems to vary from $1 \mathrm{~h}$ (enteropeptidase) to $2.5 \mathrm{~h}$ ( $\gamma$-glutamyl transferase) after the start of the perfusion. Figure 1 of course reflects the global effect including cytosol enzymes and non-enzymic proteins.

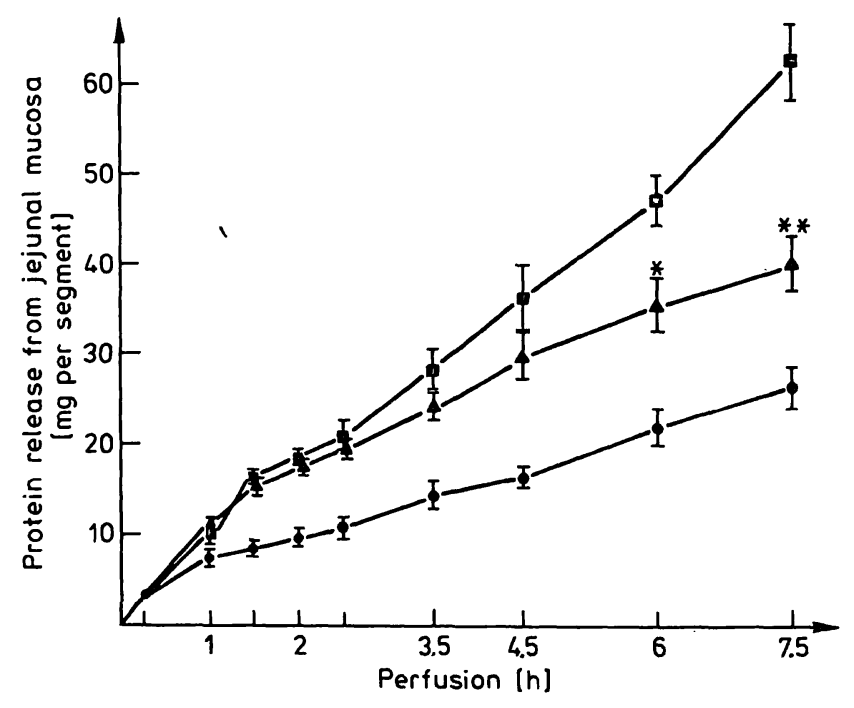

Fig. 1. Cumulative protein concentration in the perfusate as a function of time.

- - Ringer solution, D- $10 \mathrm{mmol} / \mathrm{l}$ taurocholate. $\Delta-\Delta$ the same after administration of cycloheximide. Vertical brackets at points indicate mean \pm 1 SEM. $n=5$ for Ringer, 5 for taurocholate and 6 for taurocholate + cycloheximide. $* *$, significant difference between the latter at the 1 per cent level.

\section{Discussion}

It is evident that during perfusion with bile salt an increasing proportion of the brush border enzymes and of released protein stem from de novo synthesis. A rough estimate leads to the conclusion that de novo synthesis becomes effective when about 10-30 per cent of the preformed enzymes or protein have been lost. Enzyme activities and protein content of normal jejunal mucosa were given in table 2 of our first communication (1). Unfortunately, there was an error in our calculation: the values listed in that table should be divided by 2.2 .

These results may be compared with similar investigations on the release of plasma membrane enzymes from the biliary canaliculi of the liver cells after bile duct ligation. The increase of alkaline phosphatase in both liver and serum can be inhibited by agents that interfere with nucleic acid or protein synthesis, such as ethionine, cycloheximide, actinomycin and puromycin $(2-6)$. A similar mechanism could not be demonstrated for other membrane enzymes, particularly $\gamma$-glutamyl transferase (7) and $5^{\prime}$-nucleotidase (4). On the other hand it seems impossible that in cases of chronic cholestasis markedly elevated serum levels of these enzymes (5-15 times normal) should be maintained for weeks without stimulated synthesis. A time factor may be operative. In our observations, too, the cycloheximide effect on the release of $\gamma$-glutamyl transferase by taurocholate is not demonstrable until $2.5 \mathrm{~h}$ after the start of the perfusion, i.e. after removal of 20-30 per cent of the enzyme from the membrane, in contrast to 7-14 per cent in the case of alkaline phosphatase at about $1 \mathrm{~h}$. Another example is the striking increase of urinary (tubular) alanine aminopeptidase in chronic cholestasis (8). It usually amounts to $10-15$ times the normal mean. Such excretion rates could not be maintained without a corresponding increase in the rate of synthesis. This, however, depends on the energy situation in the mucosa. In a previous communication (9) results of the in vivo method were compared with those of in vitro experiments. It is a characteristic feature of the latter that after an initial steep increase, the release rates of enzymes decline rapidly. This might be due to hypoxia and, consequently, defective synthesis, and indeed, evidence was recently provided (10) that the original Wilson-Wiseman method as used by us suffers from insufficient oxygenation. 


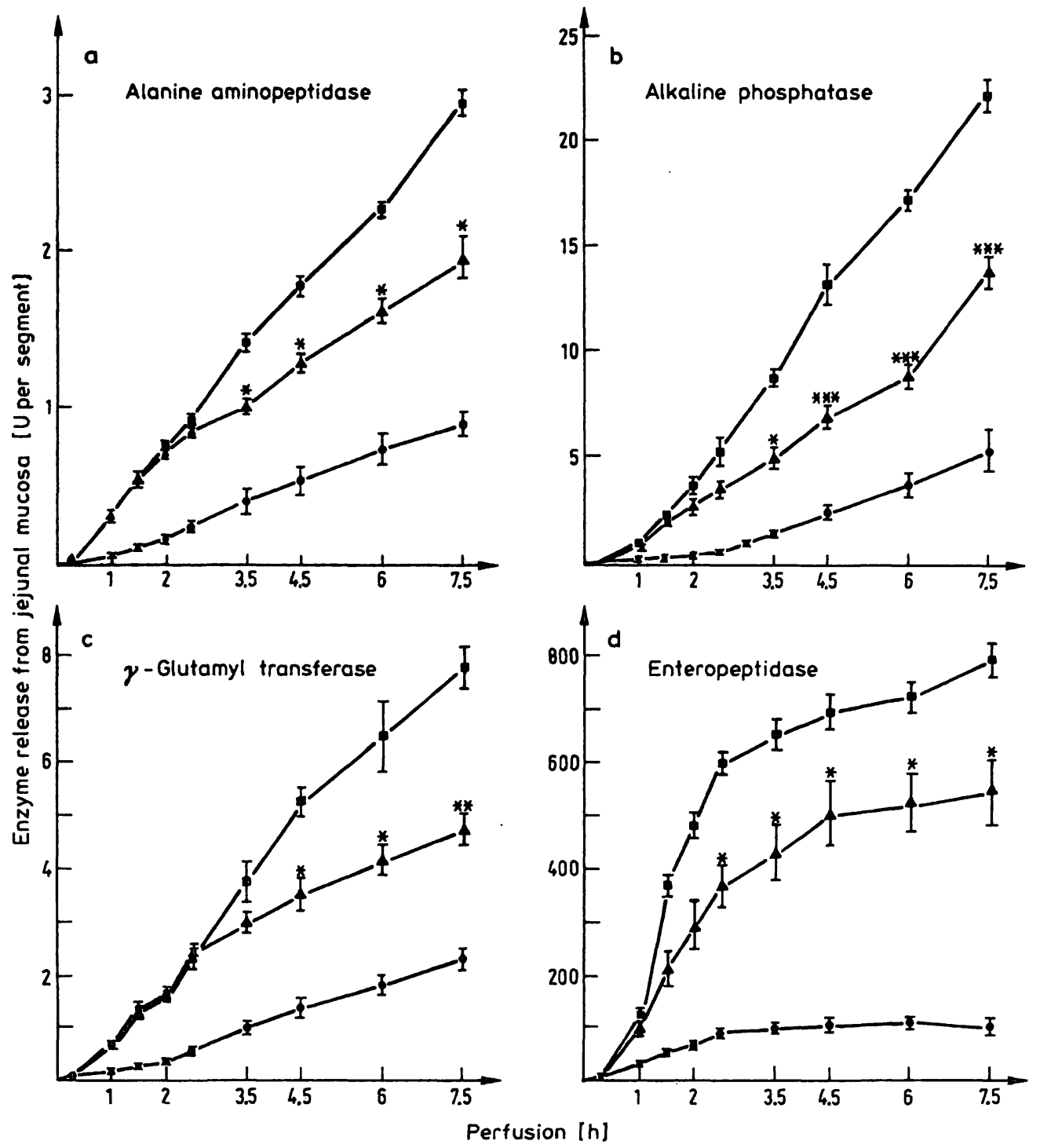

Fig. 2. Cumulative enzyme activity concentrations in the perfusate as a function of time.

a) alanine aminopeptidase

b) alkaline phosphatase

c) $\gamma$-glutamyl transferase

d) enteropeptidase

As for symbols and $n$ see fig. 1 .

Significance of differences between taurocholate release without and with previous cycloheximide administration:

$* \mathrm{p}<0.05, * * \mathrm{p}<0.01, * * * \mathrm{p}<0.001$

\section{References}

1. Bossmann, B. \& Hascheñ, R. J. (1983) J. Clin...Chem. Clin. Biochem. 21, 1-9.

2. Börnig, H., Śtepán, J., Horn, A., Giẹrtler, R., Thiele, G. \&

- Večerek, B. (1967) Hoppe-Seyler's Z. Physiol. Chem. 348. 1311-1318.

3. Kaplan, M. M. \& Righetti, A. (1970) J. Clin. Invest. 49. 508-516.

4. Righetti, A. \& Kaplan, M. M. (1972) Gastroenterology 62, 1034-1039.

5. Kryszewski, A. J., Neals, G., Whitfield, J. B. \& Moss, D. W. (1973) Clin. Chim. Acta 47, 175-182.
6. Schlaeger, R., Haux, P. \& Kattermann, R. (1982) Enzyme $28,3-13$.

7. Huseby, N.-E. \& Vik, T. (1978) Clin. Chim. Acta 88, 385392.

8. Burchardt, U., Peters, J. E., Neof, L., Gründig, C. A. \& Haschen, R. J. (1977) Z. Med. Labor.-Diagn. 18, 190-212.

9. Bossmann, B. \& Haschen, R. J. (1983) J. Clin. Chem. Clin. Biochem. 21, 659-663.

10. Ekkert, L. G. \& Ugolev, A. M. (1982) Gen. Physiol. Biophys. 2, 141-157.
Dr. Bärbel Bossmann

Martin-Luther-Universität

Halle-Wittenberg

Institut für Klinische Biochemie

Leninallee 2

DDR-4020 Halle 
$\therefore \quad$. 